\title{
Kernel current source density method
}

\author{
Jan Potworowski ${ }^{*}$, Wit Jakuczun ${ }^{2}$, Szymon Łęski ${ }^{1}$, Daniel K Wójcik ${ }^{1}$ \\ From Twentieth Annual Computational Neuroscience Meeting: CNS*2011 \\ Stockholm, Sweden. 23-28 July 2011
}

Local field potentials (LFP), the low-frequency part of extracellular electric potential, reflect dendritic processing of synaptic inputs to neuronal populations. They are an invaluable tool in the studies of neural activity both in vivo and in vitro. With recent fast development of multielectrode technology one can easily record potentials in different geometries, including 3D setups, from multiple sites simultaneously. Due to the longrange nature of electric field each electrode may reflect activity of sources located millimeters away which complicates analysis of LFP. Whenever possible it is convenient to estimate the sources of measured potential, called current source density (CSD), which is the volume density of net transmembrane currents. CSD directly reflects the local neural activity and current source density analysis is often used to analyze LFP.

In homogeneous and isotropic tissue CSD is given by the Laplacian of the potentials, so discrete differentiation is the simplest estimate for a set of potentials on a regular grid. Recently continuous methods for CSD estimation have been developed, called the inverse CSD (iCSD). These methods assume a specific parametric form of CSD generating potentials and calculate the LFP in a forward-modeling scheme to obtain the values of CSD parameters. The iCSD framework assumes CSD distributions parameterized with as many parameters as there are measurements.

Here we present a nonparametric method for CSD estimation based on kernel techniques. Kernel Current Source Density method lets the user specify the family of allowed CSD distributions through a basis of dimensionality much larger than the number of measurements. Prior knowledge of the anatomy or physiology of the probed structure, such as laminarity, can be incorporated in the method. KCSD can be applied to recordings from electrodes distributed arbitrarily on one-, two, and three-dimensional sets so one can consider experimental setups optimally adapted to a research problem of interest (Figure 1). We show that kCSD is a general non-parametric framework for CSD estimation including

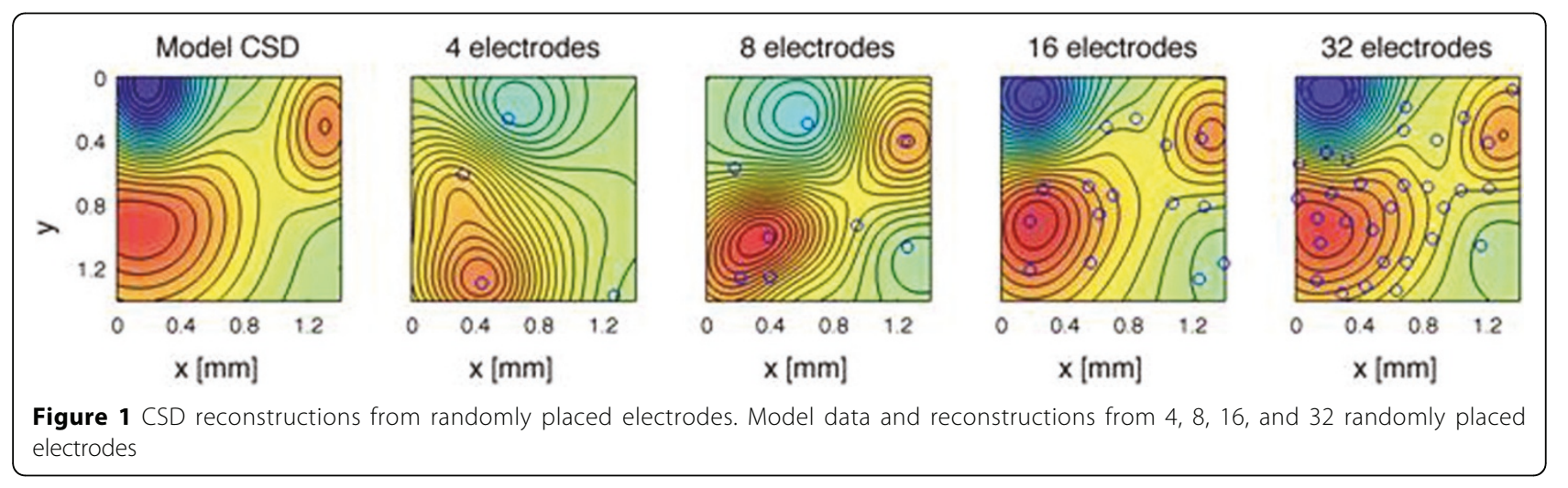

\footnotetext{
* Correspondence: j.potworowski@nencki.gov.pl

'Laboratory of Neuroinformatics, Nencki Institute of Experimental Biology,

Warsaw, 02-093, Poland

Full list of author information is available at the end of the article
}

\section{() Biomed Central}

(c) 2011 Potworowski et al; licensee BioMed Central Ltd. This is an open access article distributed under the terms of the Creative Commons Attribution License (http://creativecommons.org/licenses/by/2.0), which permits unrestricted use, distribution, and reproduction in any medium, provided the original work is properly cited. 
all the previous variants of iCSD methods as special cases.

\section{Acknowledgements}

Supported by the Polish Ministry of Science and Higher Education grant PBZ/MNiSW/07/2006/11 and by the infrastructural grant from the Polish Ministry of Regional Development, POIG.02.03.00-00-003/09.

\section{Author details}

'Laboratory of Neuroinformatics, Nencki Institute of Experimental Biology,

Warsaw, 02-093, Poland. WLOG Solutions, Warsaw, 02-389, Poland.

Published: 18 July 2011

\section{References}

1. Nicholson C, Freeman JA: Theory of current source-density analysis and determination of conductivity sensor for anuran cerebellum. $J$ Neurophysiol 1975, 38:356-368.

2. Pettersen KH, Devor A, Ulbert I, Dale AM, Einevoll GT: Current-source density estimation based on inversion of electrostatic forward solution: effects of finite extent of neuronal activity and conductivity discontinuities. J Neurosci Methods 2006, 154:116-133.

3. Łęski S, Wójcik DK, Tereszczuk J, Świejkowski DA, Kublik E, Wróbel A: Inverse Current-Source Density in three dimensions. Neuroinformatics 2007, 5:207-222.

doi:10.1186/1471-2202-12-S1-P375

Cite this article as: Potworowski et al:: Kernel current source density method. BMC Neuroscience 2011 12(Suppl 1):P375.

\section{Submit your next manuscript to BioMed Central} and take full advantage of:

- Convenient online submission

- Thorough peer review

- No space constraints or color figure charges

- Immediate publication on acceptance

- Inclusion in PubMed, CAS, Scopus and Google Scholar

- Research which is freely available for redistribution

Submit your manuscript at www.biomedcentral.com/submit 